\title{
The Role of Neurokinin B Signalling in Reproductive Neuroendocrinology
}

\author{
P. Grachev ${ }^{a}$ R.P. Millar ${ }^{\text {b-d }}$ K.T. O'Byrne ${ }^{a}$
}

${ }^{a}$ Division of Women's Health, School of Medicine, King's College London, London, and ${ }^{b}$ Centre for Integrative Physiology, University of Edinburgh, Edinburgh, UK; ${ }^{\mathrm{C} M a m m a l}$ Research Institute, University of Pretoria, Pretoria, and d UCT/MRC Receptor Biology Group, University of Cape Town, Cape Town, South Africa

\section{Key Words}

Neurokinin B · Kisspeptin · Dynorphin A .

Gonadotropin-releasing hormone · Luteinising hormone

\begin{abstract}
The KNDy neuropeptides, kisspeptin, neurokinin B (NKB) and dynorphin $A(D y n)$, have been implicated in regulating pulsatile luteinising hormone (LH) secretion. Studies of the interactions between KNDy signalling systems, however, are currently few. Although the stimulatory effect of kisspeptin and the inhibitory effect of Dyn on the gonadotropin-releasing hormone pulse generator are widely accepted, the effects of NKB in rodents are variable and sometimes controversial. Literature describing increased $\mathrm{LH}$ secretion in response to NKB receptor agonism predominates and is in line with human physiology, as well as the pathophysiology of pubertal failure associated with disruption of NKB signalling. However, the robust suppression of the LH pulse, induced by the same treatment under hypoestrogenic conditions, may hold clues as to the mechanisms of reproductive inhibition under pathological conditions. This review discusses the recent evidence for this paradox and outlines a revised working model incorporating the mechanisms by which KNDy neuropeptides modulate the reproductive axis.
\end{abstract}

\section{KARGER}

E-Mail karger@karger.com

www.karger.com/nen

\section{Introduction}

Episodic release of gonadotropin-releasing hormone $(\mathrm{GnRH})$ into the hypophyseal portal circulation coordinates the pituitary secretion of gonadotropins (luteinising hormone, $\mathrm{LH}$, and follicle-stimulating hormone, FSH), which stimulate the gonads to produce gametes and secrete sex steroids (oestrogens, progesterone and testosterone) and, thereby, drive the reproductive system [1]. Although GnRH neurones have been shown to possess inherent rhythmicity and an ability to synchronise firing [2-5], bursts of electrical activity of $\mathrm{GnRH}$ neurones in vitro/ex vivo rarely occur at frequencies concomitant with LH pulses in the living animal [6]. To describe the pulsatile release of $\mathrm{GnRH} / \mathrm{LH}$, the term $\mathrm{GnRH}$ pulse generator was coined [7]. Despite over 40 years of ensuing research this elusive entity is still considered a necessary concept to explain the discrepancy in the frequencies of isolated GnRH neurone firing and pulses of $\mathrm{LH}$ in the systemic circulation. It is well recognised that peptidergic signalling mechanisms modulate the $\mathrm{GnRH}$ pulse generator [8] and are thus important regulatory components of the hypothalamic-pituitary-gonadal (HPG) axis. In particular, the neuropeptides neurokinin B (NKB) [9] and kisspeptin $[10,11]$ have been shown to be indispensable for physiological development and function of the human reproductive system. Their colocalisation with an 
opioid peptide, dynorphin A (Dyn) within a subset of neurones in the hypothalamic arcuate nucleus (ARC) [12], which project to the medial preoptic area (mPOA) [13] and median eminence (ME) [14] where contacts with GnRH neurones have been documented in several species [14-20] (see [21] for a recent review), raises great interest in this kisspeptin-NKB-Dyn neuronal population (referred to as KNDy neurones) as the possible substrate of the GnRH pulse generator.

\section{Mechanisms of KNDy Signalling}

The mechanisms whereby kisspeptin influences the HPG axis seem relatively straightforward: GnRH neurones express kisspeptin receptors (GPR54) [17, 22], are exquisitely sensitive to kisspeptin originating from neurones of the ARC [23] and the anteroventral periventricular nucleus [17, 24, 25], as well as exogenous kisspeptin [26-30], and are consistently driven to secrete GnRH in either a phasic or continuous fashion apparently dependent on the frequency of kisspeptinergic stimulation [31, 32]. However, the kisspeptin-dependent nature of the HPG axis is challenged by a report that mice lacking kisspeptin neurones exhibited normal reproductive development, whereas kisspeptin neurone ablation in adulthood rendered mice infertile, suggesting the development of compensatory mechanisms [33].

Dyn has long been known to decrease GnRH pulse frequency [34], and its primary role as such has been postulated to be in mediating the negative feedback effects of progesterone $\left(\mathrm{P}_{4}\right)$ on the neuroendocrine hypothalamus [35]. The א-opioid receptor (KOR), through which Dyn preferentially signals [36], is not abundantly expressed in the vicinity of GnRH neurones [37, 38]. It was, therefore, hypothesised that Dyn neurones affect GnRH secretion via a yet undiscovered intermediary signalling system. Currently accepted models propose that kisspeptin acts as a trigger for GnRH release, while Dyn terminates each GnRH pulse [39], although conclusive evidence for the latter notion is currently lacking. A plausible hypothesis is that Dyn, released from ARC KNDy neurones, acts in an autocrine or paracrine modality to inhibit the activity of kisspeptin neurones. Indeed, KOR is expressed by mouse KNDy neurones [35], and application of KOR agonists to ex vivo murine hypothalamic slices strongly suppresses the firing rate of GFP-labelled ARC kisspeptin neurones [40, 41]. However, the stimulatory effects of the KOR antagonist norbinaltorphimine on pulsatile LH secretion in the rat seem to be estradiol $\left(\mathrm{E}_{2}\right)$-dependent
[42], suggesting that a Dyn-ergic tone endogenous to the ARC may only participate in GnRH pulse regulation in the presence of physiological levels of gonadal steroids. This observation conflicts with the notion that Dyn might terminate $\mathrm{GnRH}$ pulses, since pulsatile LH secretion is preserved in postmenopausal women [43] and ovariectomised (OVX) rodents [44, 45] alike.

In contrast to kisspeptin/GPR54 signalling, the mechanisms by which NKB signalling influences HPG axis function appear more complex. NKB preferentially binds and activates the neurokin 3 receptor (NK3R), although promiscuous binding to other neurokinin receptor subtypes has been implicated in the modulatory actions of NKB signalling in rodents $[40,46]$. The initial report of suppressed LH secretion following selective activation of $\mathrm{NK} 3 \mathrm{R}$ in OVX $+\mathrm{E}_{2}$ rats [47] prompted similar experiments in other species. Subsequent reports of stimulation of $\mathrm{LH}$ secretion in response to administration of the selective NK3R agonist, senktide, in the mouse [35], rat [48], goat [49], sheep [50,51] and monkey [52, 53], together with the discovery that inactivating mutations in human genes encoding NKB (TAC3) and NK3R (TACR3) result in hypogonadotropic hypogonadism $[9,54-56]$, questioned the previous report of HPG axis inhibition by central administration of the agonist [47]. A mechanism for NKB stimulation of $\mathrm{LH}$ secretion was then proposed, when it was shown that the increase in LH secretion associated with NK3R agonism is dependent upon kisspeptin/GPR54 signalling in the prepubertal male monkey [53]. This was supported by the observation that kisspeptin infusion restored LH pulsatility in humans with inactivating mutations in TAC3 or TACR3 [54]. In the light of apparent species differences, it was required to determine whether a similar kisspeptinergic mechanism underlies the NKB-induced stimulation of $\mathrm{LH}$ secretion in rodents. The LH-secreting action of senktide was indeed absent in GPR54 knockout mice [57]. It was subsequently confirmed that the GnRH pulse generator in ovary-intact prepubertal female rats responds to intracerebroventricular administration of senktide by eliciting single LH pulses in a kisspeptin/GPR54-dependent fashion [58]. The physiological significance of this peptidergic mechanism is, however, questioned by the report that mice lacking functional NK3R are capable of pubertal development and fertility [59], which contrasts with observations in humans $[9,54-56]$. Either way, evidence for both stimulatory and inhibitory effects of $\mathrm{NKB}$ on the rat reproductive axis $[44,45,47,48]$ highlights the importance of elucidating the underlying mechanisms in different physiological states and in a range of species. 
It was demonstrated that, at least in the female, gonadal status determines the response of the HPG axis to treatment with agonists of NK3R. In the OVX rat, intracerebroventricular administration of senktide significantly reduced LH levels [48]. Conversely, senktide caused an increase in LH secretion in OVX rats chronically replaced with proestrus levels of $\mathrm{E}_{2}$ [48]. Moreover, in follicular-phase ewes, intracerebroventricular injection of senktide was able to increase $\mathrm{LH}$ secretion, but it had no effect in luteal-phase ewes [50]. This prompted our studies on the roles of gonadal steroids in modulating the effects of intracerebroventricular administration of senktide in OVX rats. These studies provided definitive evidence that the presence of neither low levels of $\mathrm{E}_{2}$ $(35.8 \pm 1.2 \mathrm{pg} / \mathrm{ml})$ nor low levels of $\mathrm{P}_{4}(16.7 \pm 1.5 \mathrm{ng} / \mathrm{ml})$ [60] alters the dynamics of senktide-induced suppression of the GnRH pulse generator [44]. Ovary-intact diestrous $[44,48]$ and prepubertal rats [58] showed a consistent increase in LH levels following intracerebroventricular administration of senktide. Curiously, senktide arrested pulsatile secretion of $\mathrm{LH}$ in OVX rats replaced with $\mathrm{E}_{2}$ levels comparable to diestrous rats $(83.3 \pm 14.2 \mathrm{pg} / \mathrm{ml})$ [45]. Notably, however, more subtle changes in circulating $\mathrm{E}_{2}$ levels, such as those occurring through the oestrous cycle, failed to reverse the stimulatory effects of senktide administration on LH secretion [48]. Taken together, these findings suggest that over a broader spectrum of $\mathrm{E}_{2}$ concentrations the $\mathrm{GnRH}$ pulse generator responds differently to central NK3R agonism. The high degree of oestrogen receptor- $\alpha$ colocalisation with NKB within ARC neurones $[12,61]$ provides the mechanistic machinery for these biphasic effects. There is perhaps a physiological threshold of circulating $\mathrm{E}_{2}$ levels, which sees reversal of the NKB-induced stimulation of LH secretion. This threshold is likely to be species- and even strain-specific, since the polymorphisms that distinguish the structures of oestrogen receptor- $\alpha$ expressed by different rat strains [62] are potentially capable of giving rise to differences in sensitivity to $\mathrm{E}_{2}$ [63-67]. However, the mechanism whereby NKB can both stimulate and suppress LH secretion remains cryptic.

\section{Mechanisms of NKB Suppression of the GnRH Pulse Generator}

Because both stimulatory and inhibitory effects of central senktide administration are observed in the female rat, NKB was hypothesised to have dual and opposite roles in the control of the $\mathrm{GnRH}$ pulse generator. The blockade of senktide-induced LH pulses in prepubertal rats by pretreatment with a GPR54 antagonist [58], as well as an absence of senktide-induced stimulation of LH secretion by GPR54 knockout in male mice [57], suggests that $\mathrm{GnRH}$ neurones are stimulated by kisspeptin released as a result of NK3R activation. However, the mechanism by which senktide is able to suppress LH pulses under hypoestrogenic conditions $\left(\mathrm{OVX}+/-\operatorname{low~}_{2} / \mathrm{P}_{4}\right)$ is unclear. Senktide administered intracerebroventricularly can reach and activate NK3R expressed by a wide range of neuronal populations $[68,69]$. Therefore, to determine whether the ARC population of KNDy neurones is involved in mediating the observed suppression of pulsatile LH secretion in response to intracerebroventricular administration of senktide, we targeted injections of the NK3R agonist to exclusively reach the ARC. In OVX rats, intra-ARC administration of senktide achieved a similar dose-dependent suppression of LH secretion to that observed with intracerebroventricular administration, albeit at a fraction of the dose [45]. Senktide administered through misplaced cannulae had no effect on LH secretion, thus confirming that $\mathrm{ARCNKB}$ neurones are indeed responsible for the observed suppression of the $\mathrm{GnRH}$ pulse generator [45]. NK3R is abundantly expressed by $\mathrm{NKB} / \mathrm{Dyn}$ neurones in the rat ARC [12], as well as in ovine KNDy neurones [70], thus intra-ARC administration of senktide pharmacologically mimics the local effects of NKB-ergic volume transmission events that are suggested to underlie the suppression of the GnRH pulse generator. The notion of NKB-ergic autoregulation in the $\mathrm{ARC}$ is supported by the evidence for numerous bilateral interconnections between ARC NKB neurones [13, 14].

The feasibility of direct effects of KNDy peptides on the HPG axis can be assessed by means of a detailed neuroanatomical analysis of the connections between KNDy and GnRH neurones. NKB neurones of the ARC have been shown to innervate both the perikarya and axon termini of GnRH neurones. However, the latter express far more abundant NK3R [14], which strongly suggests that ARC NKB neurones projecting to the ME might suppress neurosecretion of $\mathrm{GnRH}$ from axon terminals. Because the extracellular milieu of the ME is separated from that of the ARC by the blood-brain barrier [71, 72], the only possible sources of $\mathrm{NKB}$ reaching $\mathrm{GnRH}$ axon terminals are the projections of ARC NKB neurones. Systemic administration of senktide should reach all NK3Rs outside the blood-brain barrier, including those expressed at terminals of $\mathrm{GnRH}$ axons in the ME. With this assumption, three doses of senktide $(0.65-65 \mathrm{nmol} / \mathrm{kg})$ were administered intravenously to conscious, freely moving OVX + 
Fig. 1. Effect of peripheral administration of an NK3R agonist on pulsatile LH secretion. Representative LH profiles demonstrating the effect of intravenous administration of a selective NK3R agonist, senktide (b-d), or vehicle (a), on pulsatile LH secretion in $\mathrm{OVX}+\mathrm{E}_{2}$ rats. Peripheral administration of senktide had no effect on pulsatile $\mathrm{LH}$ secretion irrespective of the dose, as summarised in e $(n=4-7$ per group).

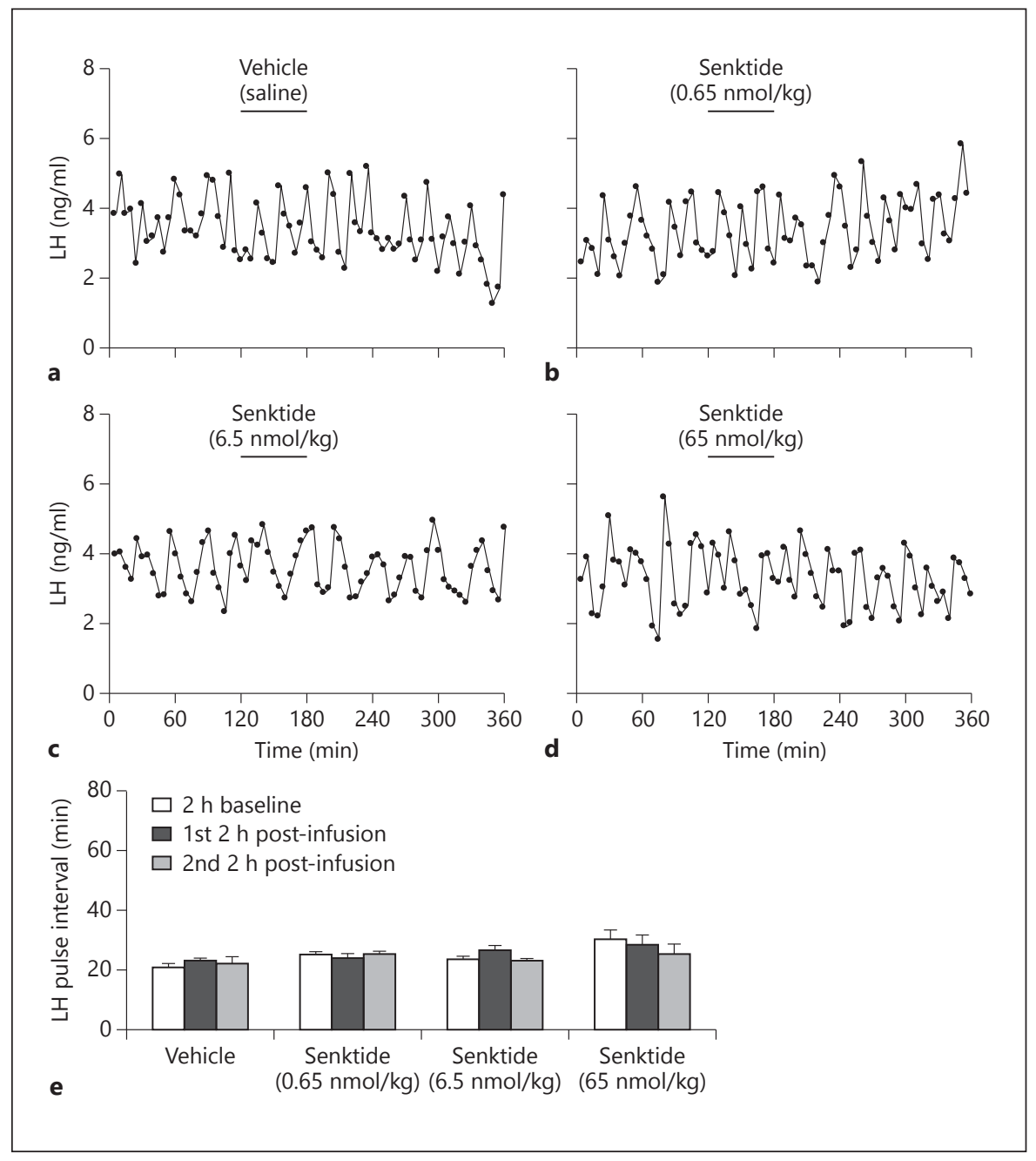

$\mathrm{E}_{2}$ rats in order to simulate efflux of $\mathrm{NKB}$ from projections of ARC NKB neurones into the ME. Surprisingly, none of the three doses of senktide administered this way had a detectable effect on pulsatile LH secretion within $4 \mathrm{~h}$ of administration (fig. 1), although comparable doses potently stimulated LH secretion in male monkeys [52]. These data are in agreement with the only previous study investigating the effect of peripheral (intraperitoneal) administration of NKB on LH secretion in the rodent [73], which also suggests a lack of an acute effect of NK3R activation outside the blood-brain barrier, including those expressed at the surface membranes of GnRH axon terminals in the ME. Therefore, the rodent blood-brain barrier is unlikely to be permeable to senktide, and there remains no functional evidence to suggest that ARC neurones secrete $\mathrm{NKB}$ into the $\mathrm{ME}$ in order to alter the pulsatile pattern of GnRH neurosecretion. Thus, the role of NK3R expressed at GnRH terminals in the ME [14] is a conundrum, particularly since it has recently been shown that $\mathrm{GnRH}$ terminals within male mouse brain slices secrete GnRH in response to bath application of senktide [74], but the electrical activity of GnRH neurones within such slices is unaffected by senktide [75]. Furthermore, unlike in the rat, ovine GnRH neurones appear to be altogether devoid of NK3R [70]. It is also important to recognise that the identification of NK3R in GnRH terminals in the ME is based on immunohistochemistry [14], and functional binding has not been demonstrated.

A possibility is that the effects of NKB secreted within the ARC are mediated through NK3R expressed along projection structures of $\mathrm{GnRH}$ neurones that pass through the $\mathrm{ARC}$ en route to the ME. In the 'artificial follicularphase' $\left(\mathrm{OVX}+\mathrm{E}_{2}+\mathrm{P}_{4}\right)$ ewes, some $17 \%$ of ARC KNDy 
neurones receive GnRH inputs [51] and, although their origin has not been explored, such structures have been shown to simultaneously display synaptic and conductive properties typically associated with dendrites and axons, respectively [76]. In fact, it was recently reported that as many as half of female mouse ARC kisspeptin neurones are in direct contact with GnRH axon varicosities [77]. Notably, in light of these novel findings, one needs to question the robustness of previous efforts to identify NK3R/GnRH coexpression. Future studies will undoubtedly aim to localise functional NK3R expression to specific regions along $\mathrm{GnRH}$ processes, including the ARC.

Another possible mechanism by which ARC NKB neurones might suppress the $\mathrm{GnRH}$ pulse generator is through inhibition of kisspeptinergic stimulation of GnRH neurosecretion, perhaps involving Dyn/KOR signalling. Several lines of evidence serve to substantiate this hypothesis: (1) the suppression of the LH pulse by central administration of senktide is dependent on Dyn/KOR signalling $[44,45],(2)$ the anatomy of KNDy neurones permits direct negative autoregulation by Dyn [12, 35, 39], (3) Dyn or its synthetic analogue, U50488, have been shown to reduce the rate of spontaneous firing of murine KNDy neurones [40, 41] and (4) central administration of senktide or U50488 attenuates kisspeptin-induced LH secretion in male rats [78]. On the other hand, studies addressing this hypothesis have predominantly been conducted in animal models in which the effect of senktide on the HPG axis is stimulatory. It is hardly surprising, therefore, that electrophysiological data, such as that describing NKB- or senktide-induced KNDy neurone firing in male mice $[40,75]$, do not fit this hypothetical mechanism. Indeed, if similar experiments were to be performed in OVX rats, for instance, it is expected that NKB or senktide would cause local secretion of Dyn, concomitant with a period during which KNDy neurones are silent and the associated lack of kisspeptin secretion disallows episodic neurosecretion of GnRH. These predictions, although speculative, are backed by observations that $\mathrm{LH}$ pulses $[44,45]$ and ARC multiunit electrical activity volleys [44] are abrogated in OVX rats injected centrally with senktide, and are intended to stimulate further studies to interrogate the posed hypothesis.

Intriguingly, intra-ARC administration of senktide also caused a reduction in Gnrh1 and Kiss1r mRNA expression in the mPOA [45]. Thus, increased NKB/NK3R signalling in the ARC can also have long-term repercussions on GnRH neurones. Because these effects were observed several hours after the recovery of the basal LH pulse from a period of senktide-induced suppression, they are likely the result of reduced GnRH neurone activity as opposed to a mechanism by which pulsatile LH secretion is diminished following intra-ARC senktide administration. Following a period of prolonged lack of activation GnRH neurones might downregulate Gnrh1 mRNA expression in order to attenuate peptide synthesis in the presence of accumulated peptide, although further studies are required to determine whether this is the case. Furthermore, the senktide-induced reduction in $\mathrm{mPOA}$ Gnrh1 and Kiss1r mRNA expression is reminiscent of corticotrophin-releasing factor (CRF)-mediated mechanisms that diminish GnRH pulse generator frequency and sensitivity to kisspeptinergic stimulation following acute exposure to stress [79]. For this reason, we investigated the possible involvement of CRF and related stressassociated neuropeptide, arginine vasopressin (AVP), in mediating the suppressive effects of central administration of senktide on the HPG axis. Despite evidence that central administration of NK3R agonists induces expression of c-Fos (marker of neuronal activation) in CRF and AVP neurones [80, 81] and increases adrenocorticotrophic hormone and corticosterone release [82], neither CRF nor AVP receptor antagonists prevented the senktide-induced suppression of the GnRH pulse generator [83]. ARC NKB neurones are therefore unlikely to recruit these elements of the HPA axis to suppress the GnRH pulse generator. Nevertheless, NKB/NK3R signalling does appear to be involved in the stress-induced suppression of the LH pulse, since pretreatment with an NK3R antagonist significantly reduced the extent to which acute inflammation (intravenous endotoxin challenge) suppressed pulsatile LH secretion and stimulated corticosterone release in OVX rats [83]. Future experiments should determine which neuronal populations secrete and respond to $\mathrm{NKB}$ as part of a mechanism of GnRH pulse generator suppression by immunological stress.

\section{Dyn and NKB: Partners in Crime?}

Of the three KNDy neuropeptides, Dyn has been the longest subject of neuroendocrine research [84] and its suppressive effects on LH secretion have been well documented over the past three decades [85]. However, the interaction of this opioid peptide with kisspeptin and NKB signalling systems has not been extensively studied. In the female rat most Dyn-immunoreactive neurones in the ARC express NK3R [12], thus it has been postulated that Dyn/KOR signalling is involved in the senktide-induced suppression of pulsatile LH secretion. Indeed, the 
inhibitory effect of intracerebroventricular senktide administration on LH secretion was blocked as effectively by pretreatment with a KOR antagonist as by an NK3R antagonist [44]. Subsequently, the Dyn/KOR-dependent nature of senktide-induced LH pulse suppression was confirmed by targeting KOR antagonist and senktide administration to the ARC bilaterally [45]. These findings suggest that the intimate coexistence of $\mathrm{NKB}$ and Dyn within KNDy neurones is what enables ARC NKB/NK3R signalling events to generate inhibitory signals that subsequently suppress pulsatile secretion of $\mathrm{GnRH}$ and therefore LH.

Confirmation of the involvement of Dyn/KOR signalling did not provide a comprehensive understanding of the mechanism of senktide-induced suppression of the $\mathrm{GnRH}$ pulse generator. Although Dyn/NKB fibres have been detected (using immunocytochemistry) throughout the hypothalamus, including the ME and MPOA [12], in situ hybridisation studies have not detected KOR mRNA in GnRH neurones [37, 38]. Moreover, although Goodman et al. [86] revealed Dyn-ergic synapses between Dyn axon terminals and mPOA GnRH somata using electron microscopy, they were reluctant to comment on the functional importance of this observation without evidence of KOR expression by ovine GnRH neurones, which to date has not materialised. In contrast, publications from the Gallo laboratory provide extensive functional evidence for sensitivity of GnRH neurones to Dyn [87-89]. Indeed, the authors show that perfusion of the MPOA with a selective KOR antagonist increased frequency of $\mathrm{LH}$ pulses in pregnant rats [87] and prevented the Dyn-mediated suppression of the LH surge in proestrus rats [88]. Furthermore, they demonstrated that anti-Dyn antibodies infused into the mPOA are capable of advancing the $\mathrm{LH}$ surge [89]. Together with the evidence of decreased mPOA expression of Dyn mRNA immediately prior to the LH surge [89], these findings strongly support the notion of dynorphinergic inhibition of GnRH neurone activity in the female rat. However, it is evident that the authors of these reports have been unable to provide adequate morphological evidence of KOR expression within $\mathrm{mPOA}$ GnRH neurones, since the only reference to such literature is a review article that mentions KOR expression in the POA without distinguishing between substructures or neuronal populations found therein [90]. Moreover, Zhen and Gallo $[87,91]$ make reference to previous efforts from their laboratory that showed that disinhibition of $\mathrm{GnRH}$ secretion following KOR blockade is a noradrenaline-dependent phenomenon, which contradicts their claims of direct action of Dyn on GnRH neu- rones. The authors cite a poster abstract as the basis of these experiments, which implies that intra-mPOA administration of Dyn suppresses the local noradrenaline tone [92]. The credibility of claims that GnRH neurones possess inherent (and direct) sensitivity to Dyn, arising solely from the laboratory of Gallo $[87-89,91]$, is compromised by the observation that $\mu$ - and $\Delta$-opioid receptor agonists, but not KOR agonists, were able to suppress the noradrenaline tone within rat mPOA slices [93]. Collectively, these data do not dispel the controversy over the mechanisms of $\mathrm{GnRH}$ pulse generator modulation by KNDy neuropeptide systems. Future studies will need to detect KOR expression within GnRH neurones using methods other than in situ hybridisation, such as duallabel immunocytochemistry and labelled ligand binding, to demonstrate more robustly the presence of KOR on $\mathrm{GnRH}$ neurones in support of a direct mechanism of Dyn-induced suppression of the GnRH pulse generator. Furthermore, the notion of noradrenergic disinhibition, as a consequence of decreased KNB/Dyn-mediated inhibitory tone, should be scrutinised as the mechanism of increased LH secretion, especially since mPOA noradrenaline signalling appears to play a key role in facilitating the transmission of various afferent signals that converge on GnRH neurones [94].

\section{Revising the Model}

Dyn/KOR signalling appears to be of less importance under conditions that favour kisspeptin/GPR54-dependent $\mathrm{LH}$ pulse generation in response to stimulation of central NK3R. This is the case in ovary-intact prepubertal rats: neither augmentation nor attenuation of Dyn/KOR signalling (by intracerebroventricular administration of KOR agonist or antagonist) had an effect on basal LH secretion [58]. Furthermore, KOR agonism/antagonism did not affect the senktide-induced LH pulses in this animal model [58]. These findings are consistent with previous reports of reduced ability of the non-selective opioid receptor antagonist, naloxone, to increase LH secretion in prepubertal mammals [95-101] and suggest that a reduction in sensitivity to Dyn might disinhibit the HPG axis, facilitating progression into puberty. Likewise, GnRH neurones are apparently able to respond to exogenous kisspeptinergic stimulation during a period of senktide-induced, Dyn/KOR-dependent suppression of pulsatile LH secretion [44]. This suggests that ARC NK3R activation diminishes the endogenous kisspeptin tone under hypoestrogenic conditions and confirms that kis-
Grachev/Millar/O’Byrne 


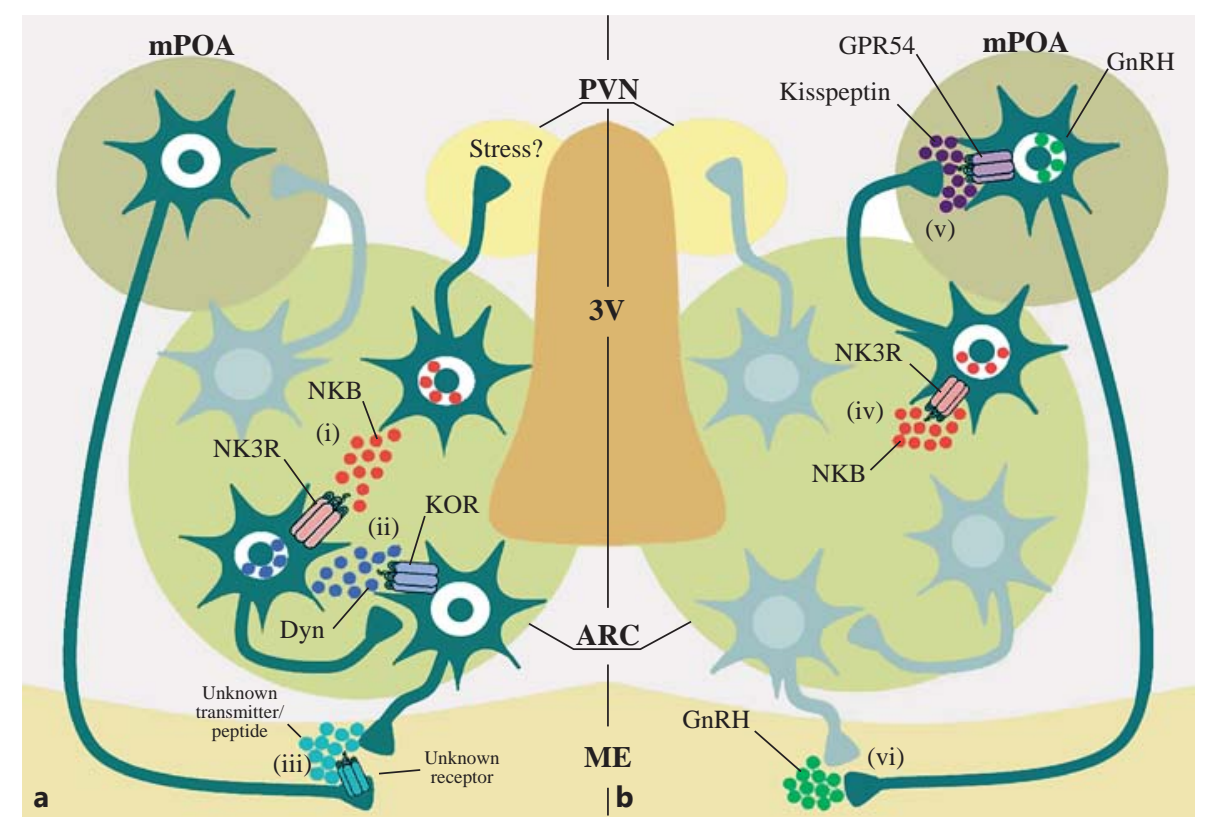

Fig. 2. A model summarising the hierarchical functional relationship between the KNDy signalling systems in the regulation of the HPG axis. NKB is the upstream bimodal regulator of $\mathrm{GnRH}$ neurosecretion through kisspeptin/GPR54 or Dyn/KOR signalling systems. Under conditions favouring the suppression of the HPG axis (a), ARC NK3R activation (i) mobilises Dyn, which activates KOR expressed by interneurones (ii) that project to terminals of GnRH neurones in the ME. This generates an NKB-driven, Dyn/KOR-dependent inhibitory stimulus that suppresses GnRH secretion via an unknown signalling system (iii). Activation of parvocellular neurones in the PVN in response to stress might

speptin is downstream of NKB in the functional hierarchy of KNDy neuropeptide signalling systems. It is apparent that two distinct downstream signalling systems that mediate the opposite effects of central senktide administration on LH secretion are differentially regulated by the gonadal steroid milieu: in a low- $\mathrm{E}_{2}$ environment (such as that in OVX rats with or without replacement of $E_{2}$ to yield circulating levels comparable to those at diestrus) senktide recruits a Dyn/KOR signalling mechanism to suppress the LH pulse $[44,45]$ (fig. 2a), while activation of NK3R elicits kisspeptin-induced LH pulses in intact prepubertal female rats [58] and increases LH levels in diestrous rats [44] (fig. 2b).

The $E_{2}$ threshold at which there is a reversal of the effects of senktide on LH secretion has yet to be determined. However, such a threshold is apparent from the direct comparison of the response of OVX rats, replaced with low (diestrus) [45] and high (proestrus) [48] levels of $\mathrm{E}_{2}$, to central senktide administration. In ovary-intact ani- activate such inhibitory circuitry to suppress the GnRH pulse generator. Conversely, under conditions that preferentially increase GnRH secretion (b) the binding of NKB to NK3R on ARC kisspeptin neurones (iv) projecting to $\mathrm{GnRH}$ perikarya in the $\mathrm{mPOA}$ stimulates kisspeptin secretion, which activates GPR54 on GnRH neurones (v), augmenting GnRH synthesis and/or release (vi). KNDy neurones may function as the GnRH pulse generator, mediating the influence of extrinsic stimuli, which prescribe the conditions for the switch between the stimulatory and inhibitory pathways in this system, on the GnRH pulse. PVN = Paraventricular nucleus. mals experiencing perhaps less extreme and/or comparatively short-term changes in $\mathrm{E}_{2}$ as part of the oestrous cycle [48] than those conferred by OVX and chronic $\mathrm{E}_{2}$ replacement, there is no obvious reversal of the effects of central senktide administration on LH secretion. Studies to address this discrepancy, as well as the underlying mechanism, are currently ongoing in our laboratory.

The notion of a stimulatory role of NKB in driving HPG axis function through partnership with kisspeptin concurs with the situation in human physiology and pathophysiology. Levels of NKB message [102] and immunoreactivity [103], as well as Kiss 1 and Kiss $1 r$ mRNA expression $[104,105]$, increase through the prepubertal period, peaking at puberty. Moreover, exogenous kisspeptin is able to advance pubertal onset in the rat [106], while administration of a kisspeptin antagonist delays puberty in this animal model [107]. Similarly, hypertrophy of kisspeptin and NKB neurones can be observed in postmenopausal women and OVX rats, concomitant with an 
increase in GnRH secretion and LH levels following the decline in $\mathrm{E}_{2}$ negative feedback [108]. Likewise, a role for NKB in stimulating GnRH neurosecretion via a kisspeptinergic mechanism in experimental animal models is supported by reports of human loss-of-function mutations in TAC3 and TACR3, causing decreased gonadotropin levels, hypogonadism and infertility $[9,55,56]$. Moreover, pulsatile secretion of $\mathrm{LH}$ is restored in these patients by administration of kisspeptin-10 [54], suggesting that NKB operates upstream of kisspeptin in an autostimulatory fashion. Inactivating mutations in KiSS1R cause a similar hypogonadotropic hypogonadism phenotype in humans [10,109], and gain-of-function mutations in KiSS1 and KiSS1R result in GnRH-dependent precocious puberty $[110,111]$. Taken together, these data highlight the intimate synergistic relationship between the kisspeptin/GPR54 and NKB/NK3R signalling systems in the regulation of reproductive function. However, the physiological relevance of the ability of NKB to suppress the HPG axis through recruitment of Dyn/KOR signalling is less clear.

It is apparent that absent or low $\mathrm{E}_{2}$ levels convert the stimulatory role of hypothalamic NKB/NK3R signalling in intact female rats to one of inhibition. Under such conditions of absent or weak negative and/or positive feedback effects of gonadal steroids, basal LH levels are high and an LH surge or ovulation are impossible. Incidence of such conditions in women are perhaps restricted to conditions of which hypoestrogenicity is either a feature or a cause (such as amenorrhoea, menopause, ovarian failure and ovariectomy), decline of ovarian function through pregnancy, lactation, hyperprolactinaemia, infection, immune pathology, stress, malnutrition, or a side effect of chronic and/or aggressive therapies. The roles of $\mathrm{NKB} / \mathrm{NK} 3 \mathrm{R}$ signalling under such conditions are far from clear and it remains to be established whether NKB/ NK3R signalling contributes to pathology or is brought about as a protective mechanism. In either case, NK3R would resemble a promising therapeutic target.

Evidence for the importance of hypothalamic NKB signalling in the regulation of reproductive function is mounting, and recent research has documented stimulatory and inhibitory effects in a wide range of species. Although further research would be necessary to reach a consensus on the precise role of NKB signalling in reproductive neuroendocrinology, mainly to reconcile the evident species differences encountered in this field, a vast body of literature suggests that NKB/NK3R signalling contributes significantly to the peptidergic control of pulsatile GnRH neurosecretion. Emerging reports that conflict with the predominating opinion of a stimulatory role for NKB raise important questions as to the pleiotropy of neural networks that involve NKB/NK3R signalling and their potential significance in reproductive regulation under a diversity of physiological and pathophysiological conditions. In order for reliable conclusions regarding the various regulatory roles of $\mathrm{NKB} / \mathrm{NK} 3 \mathrm{R}$ signalling to be drawn, future research efforts should substantiate existing data from each of the commonly used animal models, as well as clinical cases, ensuring the following: (1) that observations from in vitro experiments are consolidated by data gathered using whole (ideally conscious and behaving) animals, (2) that in vivo approaches encompass a range of physiological conditions with regards to gonadal status, age and environmental factors and (3) that each proposed mechanism of action is accompanied by clear anatomical evidence for each component of a proposed neural signalling pathway in a given species.

\section{Acknowledgements}

This research was supported by a Medical Research Council Centenary Early Career Award. The authors thank Angelique L. di Domenico for assistance with preparation of the figures.

\section{References}

1 Knobil E, Hotchkiss J: The menstrual cycle and its neuroendocrine control; in Knobil E, Neill J (eds): The Physiology of Reproduction. New York, Raven Press, 1988, pp 1971-1994.

-2 Krsmanovic LZ, Stojilkovic SS, Merelli F, Dufour SM, Virmani MA, Catt KJ: Calcium signaling and episodic secretion of gonadotropin-releasing hormone in hypothalamic neurons. Proc Natl Acad Sci USA 1992;89: 8462-8466.

- 3 Terasawa E, Schanhofer WK, Keen KL, Luchansky L: Intracellular $\mathrm{Ca}^{2+}$ oscillations in luteinizing hormone-releasing hormone neurons derived from the embryonic olfactory placode of the rhesus monkey. J Neurosci 1999;19:5898-5909.

4 Nunez L, Villalobos C, Boockfor FR, Frawley LS: The relationship between pulsatile secretion and calcium dynamics in single, living gonadotropin-releasing hormone neurons. Endocrinology 2000;141:20122017.

5 Richter TA, Keen KL, Terasawa E: Synchronization of $\mathrm{Ca}^{2+}$ oscillations among primate
LHRH neurons and nonneuronal cells in vitro. J Neurophysiol 2002;88:1559-1567.

6 Jasoni CL, Todman MG, Strumia MM, Herbison AE: Cell type-specific expression of a genetically encoded calcium indicator reveals intrinsic calcium oscillations in adult gonadotropin-releasing hormone neurons. J Neurosci 2007;27:860-867.

7 Dierschke DJ, Bhattacharya AN, Atkinson LE, Knobil E: Circhoral oscillations of plasma LH levels in the ovariectomized rhesus monkey. Endocrinology 1970;87:850-853. 
8 Lehman MN, Coolen LM, Goodman RL: Minireview: kisspeptin/neurokinin b/dynorphin (KNDy) cells of the arcuate nucleus: a central node in the control of gonadotropinreleasing hormone secretion. Endocrinology 2010;151:3479-3489.

-9 Topaloglu AK, Reimann F, Guclu M, Yalin AS, Kotan LD, Porter KM, Serin A, Mungan NO, Cook JR, Ozbek MN, Imamoglu S, Akalin NS, Yuksel B, O'Rahilly S, Semple RK: TAC3 and TACR3 mutations in familial hypogonadotropic hypogonadism reveal a key role for neurokinin $B$ in the central control of reproduction. Nat Genet 2009;41:354-358.

10 de Roux N, Genin E, Carel JC, Matsuda F, Chaussain JL, Milgrom E: Hypogonadotropic hypogonadism due to loss of function of the KiSS1-derived peptide receptor GPR54. Proc Natl Acad Sci USA 2003;100:10972-10976.

-11 Seminara SB, Messager S, Chatzidaki EE, Thresher RR, Acierno JS Jr, Shagoury JK, BoAbbas Y, Kuohung W, Schwinof KM, Hendrick AG, Zahn D, Dixon J, Kaiser UB, Slaugenhaupt SA, Gusella JF, O'Rahilly S, Carlton MB, Crowley WF Jr, Aparicio SA, Colledge WH: The GPR54 gene as a regulator of puberty. N Engl J Med 2003;349:1614-1627.

12 Burke MC, Letts PA, Krajewski SJ, Rance NE: Coexpression of dynorphin and neurokinin $\mathrm{B}$ immunoreactivity in the rat hypothalamus: morphologic evidence of interrelated function within the arcuate nucleus. J Comp Neurol 2006;498:712-726.

13 Krajewski SJ, Burke MC, Anderson MJ, McMullen NT, Rance NE: Forebrain projections of arcuate neurokinin B neurons demonstrated by anterograde tract-tracing and monosodium glutamate lesions in the rat. Neuroscience 2010;166:680-697.

-14 Krajewski SJ, Anderson MJ, Iles-Shih L, Chen KJ, Urbanski HF, Rance NE: Morphologic evidence that neurokinin B modulates gonadotropin-releasing hormone secretion via neurokinin 3 receptors in the rat median eminence. J Comp Neurol 2005;489:372-386.

-15 d'Anglemont de Tassigny X, Fagg LA, Carlton $\mathrm{MB}$, Colledge WH: Kisspeptin can stimulate gonadotropin-releasing hormone $(\mathrm{GnRH})$ release by a direct action at GnRH nerve terminals. Endocrinology 2008;149:3926-3932.

16 Decourt C, Tillet Y, Caraty A, Franceschini I, Briant C: Kisspeptin immunoreactive neurons in the equine hypothalamus interactions with GnRH neuronal system. J Chem Neuroanat 2008;36:131-137.

$\checkmark 17$ Ramaswamy S, Guerriero KA, Gibbs RB, Plant TM: Structural interactions between kisspeptin and GnRH neurons in the mediobasal hypothalamus of the male rhesus monkey (Macaca mulatta) as revealed by double immunofluorescence and confocal microscopy. Endocrinology 2008;149:4387-4395.

18 Uenoyama Y, Inoue N, Pheng V, Homma T, Takase K, Yamada S, Ajiki K, Ichikawa M, Okamura H, Maeda KI, Tsukamura H: Ultrastructural evidence of kisspeptin-gonadotropin-releasing hormone $(\mathrm{GnRH})$ interaction in the median eminence of female rats: implication of axo-axonal regulation of GnRH release. J Neuroendocrinol 2011;23:863-870.

- 19 Matsuyama S, Ohkura S, Mogi K, Wakabayashi Y, Mori Y, Tsukamura H, Maeda K, Ichikawa M, Okamura H: Morphological evidence for direct interaction between kisspeptin and gonadotropin-releasing hormone neurons at the median eminence of the male goat: an immunoelectron microscopic study. Neuroendocrinology 2011;94:323-332.

20 Hrabovszky E: Neuroanatomy of the human hypothalamic kisspeptin system. Neuroendocrinology DOI: 10.1159/000356903.

21 Lehman MN, Hileman SM, Goodman RL: Neuroanatomy of the kisspeptin signaling system in mammals: comparative and developmental aspects. Adv Exp Med Biol 2013; 784:27-62.

22 Herbison AE, de Tassigny X, Doran J, Colledge WH: Distribution and postnatal development of GPR54 gene expression in mouse brain and gonadotropin-releasing hormone neurons. Endocrinology 2010;151:312-321.

23 Yeo SH, Herbison AE: Projections of arcuate nucleus and rostral periventricular kisspeptin neurons in the adult female mouse brain. Endocrinology 2011;152:2387-2399.

24 Clarkson J, Herbison AE: Postnatal development of kisspeptin neurons in mouse hypothalamus; sexual dimorphism and projections to gonadotropin-releasing hormone neurons. Endocrinology 2006;147:5817-5825.

25 Clarkson J, d'Anglemont de Tassigny X, Colledge WH, Caraty A, Herbison AE: Distribution of kisspeptin neurones in the adult female mouse brain. J Neuroendocrinol 2009; 21:673-682.

26 Navarro VM, Castellano JM, Fernandez-Fernandez R, Tovar S, Roa J, Mayen A, Nogueiras R, Vazquez MJ, Barreiro ML, Magni P, Aguilar E, Dieguez C, Pinilla L, Tena-Sempere M: Characterization of the potent luteinizing hormone-releasing activity of KiSS-1 peptide, the natural ligand of GPR54. Endocrinology 2005; 146:156-163.

27 Messager S, Chatzidaki EE, Ma D, Hendrick AG, Zahn D, Dixon J, Thresher RR, Malinge I, Lomet D, Carlton MB, Colledge WH, Caraty A, Aparicio SA: Kisspeptin directly stimulates gonadotropin-releasing hormone release via $G$ protein-coupled receptor 54. Proc Natl Acad Sci USA 2005;102:1761-1766.

28 Ohkura S, Takase K, Matsuyama S, Mogi K, Ichimaru T, Wakabayashi Y, Uenoyama Y, Mori Y, Steiner RA, Tsukamura H, Maeda KI, Okamura H: Gonadotrophin-releasing hormone pulse generator activity in the hypothalamus of the goat. J Neuroendocrinol 2009;21:813-821.

29 Plant TM: The role of KiSS-1 in the regulation of puberty in higher primates. Eur J Endocrinol 2006;155(suppl 1):S11-S16.

30 Dhillo WS, Chaudhri OB, Thompson EL, Murphy KG, Patterson M, Ramachandran R, Nijher GK, Amber V, Kokkinos A, Donaldson M, Ghatei MA, Bloom SR: Kisspeptin-54 stimulates gonadotropin release most potent- ly during the preovulatory phase of the menstrual cycle in women. J Clin Endocrinol Metab 2007;92:3958-3966.

31 Choe HK, Kim HD, Park SH, Lee HW, Park JY, Seong JY, Lightman SL, Son GH, Kim K: Synchronous activation of gonadotropin-releasing hormone gene transcription and secretion by pulsatile kisspeptin stimulation. Proc Natl Acad Sci USA 2013;110:5677-5682.

32 Matsui H, Asami T: Effects and therapeutic potentials of kisspeptin analogs: regulation of the hypothalamic-pituitary-gonadal axis. Neuroendocrinology DOI: 10.1159/000357809.

-33 Mayer C, Boehm U: Female reproductive maturation in the absence of kisspeptin/GPR54 signaling. Nat Neurosci 2011;14:704-710.

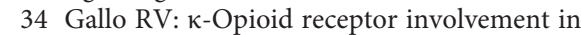
the regulation of pulsatile luteinizing hormone release during early pregnancy in the rat. J Neuroendocrinol 1990;2:685-691.

35 Navarro VM, Gottsch ML, Chavkin C, Okamura H, Clifton DK, Steiner RA: Regulation of gonadotropin-releasing hormone secretion by kisspeptin/dynorphin/neurokinin B neurons in the arcuate nucleus of the mouse. J Neurosci 2009;29:11859-11866.

- 36 Wuster M, Schulz R, Herz A: Opiate activity and receptor selectivity of dynorphin $n_{1-13}$ and related peptides. Neurosci Lett 1980;20:7983.

37 Mitchell V, Prevot V, Jennes L, Aubert JP, Croix D, Beauvillain JC: Presence of $\mu$ - and $\kappa$-opioid receptor mRNAs in galanin but not in GnRH neurons in the female rat. Neuroreport 1997;8:3167-3172.

38 Sannella MI, Petersen SL: Dual label in situ hybridization studies provide evidence that luteinizing hormone-releasing hormone neurons do not synthesize messenger ribonucleic acid for $\mu$-, $\kappa$ - or $\delta$-opiate receptors. Endocrinology 1997;138:1667-1672.

39 Goodman RL, Coolen LM, Lehman MN: A role for neurokinin B in pulsatile GnRH secretion in the ewe. Neuroendocrinology DOI: $10.1159 / 000355285$.

40 de Croft S, Boehm U, Herbison AE: Neurokinin $B$ activates arcuate kisspeptin neurons through multiple tachykinin receptors in the male mouse. Endocrinology 2013;154:2750-2760.

41 Ruka KA, Burger LL, Moenter SM: Regulation of arcuate neurons coexpressing kisspeptin, neurokinin $B$, and dynorphin by modulators of neurokinin 3 and $\kappa$-opioid receptors in adult male mice. Endocrinology 2013; 154:2761-2771.

42 Mostari P, Ieda N, Deura C, Minabe S, Yamada S, Uenoyama Y, Maeda K, Tsukamura H: Dynorphin-kappa opioid receptor signaling partly mediates estrogen negative feedback effect on LH pulses in female rats. J Reprod Dev 2013;59:266-272.

43 Lambalk CB, de Boer L, Schoute E, Popp-Snyders C, Schoemaker J: Post-menopausal and chronological age have divergent effects on pituitary and hypothalamic function in episodic gonadotrophin secretion. Clin Endocrinol (Oxf) 1997;46:439-443. 
-44 Kinsey-Jones JS, Grachev P, Li XF, Lin YS, Milligan SR, Lightman SL, O’Byrne KT: The inhibitory effects of neurokinin B on GnRH pulse generator frequency in the female rat. Endocrinology 2012;153:307-315.

- 45 Grachev P, Li XF, Kinsey-Jones JS, di Domenico AL, Millar RP, Lightman SL, O’Byrne $\mathrm{KT}$ : Suppression of the $\mathrm{GnRH}$ pulse generator by neurokinin $B$ involves a $\kappa$-opioid receptordependent mechanism. Endocrinology 2012; 153:4894-4904.

-46 Noritake K, Matsuoka T, Ohsawa T, Shimomura K, Sanbuissho A, Uenoyama Y, Maeda $\mathrm{K}$, Tsukamura $\mathrm{H}$ : Involvement of neurokinin receptors in the control of pulsatile luteinizing hormone secretion in rats. J Reprod Dev 2011;57:409-415.

-47 Sandoval-Guzman T, Rance NE: Central injection of senktide, an NK3 receptor agonist, or neuropeptide Y inhibits LH secretion and induces different patterns of Fos expression in the rat hypothalamus. Brain Res 2004;1026: 307-312.

-48 Navarro VM, Castellano JM, McConkey SM, Pineda R, Ruiz-Pino F, Pinilla L, Clifton DK, Tena-Sempere M, Steiner RA: Interactions between kisspeptin and neurokinin $\mathrm{B}$ in the control of GnRH secretion in the female rat. Am J Physiol Endocrinol Metab 2011;300: E202-E210.

-49 Wakabayashi Y, Nakada T, Murata K, Ohkura S, Mogi K, Navarro VM, Clifton DK, Mori Y, Tsukamura H, Maeda K, Steiner RA, Okamura H: Neurokinin B and dynorphin A in kisspeptin neurons of the arcuate nucleus participate in generation of periodic oscillation of neural activity driving pulsatile gonadotropin-releasing hormone secretion in the goat. J Neurosci 2010;30:31243132.

50 Billings HJ, Connors JM, Altman SN, Hileman SM, Holaskova I, Lehman MN, McManus CJ, Nestor CC, Jacobs BH, Goodman RL: Neurokinin B acts via the neurokinin-3 receptor in the retrochiasmatic area to stimulate luteinizing hormone secretion in sheep. Endocrinology 2010;151:3836-3846.

51 Goodman RL, Hileman SM, Nestor CC, Porter KL, Connors JM, Hardy SL, Millar RP, Cernea M, Coolen LM, Lehman MN: Kisspeptin, neurokinin $\mathrm{B}$, and dynorphin act in the arcuate nucleus to control activity of the $\mathrm{GnRH}$ pulse generator in ewes. Endocrinology 2013;154:4259-4269.

- 52 Ramaswamy S, Seminara SB, Ali B, Ciofi P, Amin NA, Plant TM: Neurokinin B stimulates $\mathrm{GnRH}$ release in the male monkey $(\mathrm{Ma}$ caca mulatta) and is colocalized with kisspeptin in the arcuate nucleus. Endocrinology 2010;151:4494-4503.

53 Ramaswamy S, Seminara SB, Plant TM: Evidence from the agonadal juvenile male rhesus monkey (Macaca mulatta) for the view that the action of neurokinin $\mathrm{B}$ to trigger gonadotropin-releasing hormone release is upstream from the kisspeptin receptor. Neuroendocrinology 2011;94:237-245.
54 Young J, George JT, Tello JA, Francou B, Bouligand J, Guiochon-Mantel A, Brailly-Tabard S, Anderson RA, Millar RP: Kisspeptin restores pulsatile LH secretion in patients with neurokinin B signaling deficiencies: physiological, pathophysiological and therapeutic implications. Neuroendocrinology 2013;97:193-202.

55 Young J, Bouligand J, Francou B, Raffin-Sanson ML, Gaillez S, Jeanpierre M, Grynberg M, Kamenicky P, Chanson P, Brailly-Tabard S, Guiochon-Mantel A: TAC3 and TACR3 defects cause hypothalamic congenital hypogonadotropic hypogonadism in humans. J Clin Endocrinol Metab 2010;95:2287-2295.

56 Francou B, Bouligand J, Voican A, Amazit L, Trabado S, Fagart J, Meduri G, Brailly-Tabard S, Chanson P, Lecomte P, Guiochon-Mantel A, Young J: Normosmic congenital hypogonadotropic hypogonadism due to TAC3/ TACR3 mutations: characterization of neuroendocrine phenotypes and novel mutations. PLoS One 2011;6:e25614.

57 Garcia-Galiano D, van Ingen Schenau D, Leon S, Krajnc-Franken MA, Manfredi-Lozano M, Romero-Ruiz A, Navarro VM, Gaytan F, van Noort PI, Pinilla L, Blomenrohr M, Tena-Sempere M: Kisspeptin signaling is indispensable for neurokinin B, but not glutamate, stimulation of gonadotropin secretion in mice. Endocrinology 2012;153:316-328.

58 Grachev P, Li XF, Lin YS, Hu MH, Elsamani L, Paterson SJ, Millar RP, Lightman SL, O’Byrne KT: GPR54-dependent stimulation of luteinizing hormone secretion by neurokinin $\mathrm{B}$ in prepubertal rats. PLoS One 2012;7:e44344.

59 Yang JJ, Caligioni CS, Chan YM, Seminara SB: Uncovering novel reproductive defects in neurokinin $\mathrm{B}$ receptor null mice: closing the gap between mice and men. Endocrinology 2012;153:1498-1508.

60 Cagampang FR, Maeda KI, Tsukamura H, Ohkura S, Ota K: Involvement of ovarian steroids and endogenous opioids in the fastinginduced suppression of pulsatile LH release in ovariectomized rats. J Endocrinol 1991;129: 321-328.

61 Goubillon ML, Forsdike RA, Robinson JE, Ciofi P, Caraty A, Herbison AE: Identification of neurokinin B-expressing neurons as a highly estrogen-receptive, sexually dimorphic cell group in the ovine arcuate nucleus. Endocrinology 2000;141:4218-4225.

62 Spreafico E, Bettini E, Pollio G, Maggi A: Nucleotide sequence of estrogen receptor $\mathrm{CDNA}$ from Sprague-Dawley rat. Eur J Pharmacol 1992;227:353-356.

63 Garland HO, Atherton JC, Baylis C, Morgan MR, Milne CM: Hormone profiles for progesterone, oestradiol, prolactin, plasma renin activity, aldosterone and corticosterone during pregnancy and pseudopregnancy in two strains of rat: correlation with renal studies. J Endocrinol 1987;113:435-444.

64 Emery DE, Larsson K: Rat strain differences in copulatory behavior after para-chlorophenylalanine and hormone treatment. J Comp Physiol Psychol 1979;93:1067-1084.
65 Blankenstein MA, Broerse JJ, van Zwieten MJ, van der Molen HJ: Prolactin concentration in plasma and susceptibility to mammary tumors in female rats from different strains treated chronically with estradiol-17 beta. Breast Cancer Res Treat 1984;4:137-141.

-66 Diel P, Schmidt S, Vollmer G, Janning P, Upmeier A, Michna H, Bolt HM, Degen GH: Comparative responses of three rat strains (DA/Han, Sprague-Dawley and Wistar) to treatment with environmental estrogens. Arch Toxicol 2004;78:183-193.

67 Thigpen JE, Setchell KD, Padilla-Banks E, Haseman JK, Saunders HE, Caviness GF, Kissling GE, Grant MG, Forsythe DB: Variations in phytoestrogen content between different mill dates of the same diet produces significant differences in the time of vaginal opening in CD-1 mice and F344 rats but not in CD Sprague-Dawley rats. Environ Health Perspect 2007;115:1717-1726.

68 Mileusnic D, Lee JM, Magnuson DJ, Hejna MJ, Krause JE, Lorens JB, Lorens SA: Neurokinin-3 receptor distribution in rat and human brain: an immunohistochemical study. Neuroscience 1999;89:1269-1290.

69 Nagano M, Saitow F, Haneda E, Konishi S, Hayashi M, Suzuki H: Distribution and pharmacological characterization of primate NK-1 and NK-3 tachykinin receptors in the central nervous system of the rhesus monkey. Br J Pharmacol 2006; 147:316-323.

70 Amstalden M, Coolen LM, Hemmerle AM, Billings HJ, Connors JM, Goodman RL, Lehman MN: Neurokinin 3 receptor immunoreactivity in the septal region, preoptic area and hypothalamus of the female sheep: colocalisation in neurokinin B cells of the arcuate nucleus but not in gonadotrophin-releasing hormone neurones. J Neuroendocrinol 2010; 22:1-12.

-71 Mullier A, Bouret SG, Prevot V, Dehouck B Differential distribution of tight junction proteins suggests a role for tanycytes in bloodhypothalamus barrier regulation in the adult mouse brain. J Comp Neurol 2010;518:943962.

72 Rodriguez EM, Blazquez JL, Guerra M: The design of barriers in the hypothalamus allows the median eminence and the arcuate nucleus to enjoy private milieus: the former opens to the portal blood and the latter to the cerebrospinal fluid. Peptides 2010;31:757776 .

73 Corander MP, Challis BG, Thompson EL, Jovanovic $Z$, Loraine Tung YC, Rimmington $D$, Huhtaniemi IT, Murphy KG, Topaloglu AK, Yeo GS, O’Rahilly S, Dhillo WS, Semple RK, Coll AP: The effects of neurokinin B upon gonadotrophin release in male rodents. J Neuroendocrinol 2010;22:181-187.

74 Gaskins GT, Glanowska KM, Moenter SM: Activation of neurokinin 3 receptors stimulates gonadotropin-releasing hormone $(\mathrm{GnRH})$ release in a location-dependent but kisspeptin-independent manner in adult mice. Endocrinology 2013;154:3984-3989. 
-75 Navarro VM, Gottsch ML, Wu M, GarciaGaliano D, Hobbs SJ, Bosch MA, Pinilla L, Clifton DK, Dearth A, Ronnekleiv OK, Braun RE, Palmiter RD, Tena-Sempere M, Alreja M, Steiner RA: Regulation of NKB pathways and their roles in the control of Kiss1 neurons in the arcuate nucleus of the male mouse. Endocrinology 2011;152:4265-4275.

-76 Herde MK, Iremonger KJ, Constantin S, Herbison AE: GnRH neurons elaborate a longrange projection with shared axonal and dendritic functions. J Neurosci 2013;33:1268912697.

-77 Kallo I, Vida B, Bardoczi Z, Szilvasy-Szabo A, Rabi F, Molnar T, Farkas I, Caraty A, Mikkelsen J, Coen CW, Hrabovszky E, Liposits Z: Gonadotropin-releasing hormone neurones innervate kisspeptin neurones in the female mouse brain. Neuroendocrinology, Epub ahead of print.

78 Garcia-Galiano D, Pineda R, Roa J, Ruiz-Pino F, Sanchez-Garrido MA, Castellano JM, Aguilar E, Navarro VM, Pinilla L, Tena-Sempere M: Differential modulation of gonadotropin responses to kisspeptin by aminoacidergic, peptidergic, and nitric oxide neurotransmission. Am J Physiol Endocrinol Metab 2012; 303:E1252-E1263.

-79 Kinsey-Jones JS, Li XF, Knox AM, Wilkinson ES, Zhu XL, Chaudhary AA, Milligan SR, Lightman SL, O’Byrne KT: Down-regulation of hypothalamic kisspeptin and its receptor, Kiss1r, mRNA expression is associated with stress-induced suppression of luteinising hormone secretion in the female rat. J Neuroendocrinol 2009;21:20-29.

-80 Ding YD, Shi J, Su LY, Xu JQ, Su CJ, Guo $\mathrm{XE}, \mathrm{Ju} \mathrm{G}$ : Intracerebroventricular injection of senktide-induced Fos expression in vasopressin-containing hypothalamic neurons in the rat. Brain Res 2000;882:95102.

81 Smith ME, Flynn FW: Distribution of Fos-like immunoreactivity within the rat brain following intraventricular injection of the selective $\mathrm{NK}_{3}$ receptor agonist senktide. J Comp Neurol 2000;426:413-428.

-82 Malendowicz LK, Nussdorfer GG, Warchol JB, Markowska A, Macchi C, Nowak KW, Butowska W: Effects of neuromedin-K on the rat hypothalamo-pituitary-adrenal axis. Neuropeptides 1995;29:337-341.

83 Grachev P, Li XF, Hu MH, Li SY, Millar RP, Lightman SL, O’Byrne KT: Neurokinin B signaling in the female rat: a novel link between stress and reproduction. Endocrinology DOI: 10.1210/en.2013-2038.

84 Goldstein A, Tachibana S, Lowney LI, Hunkapiller M, Hood L: Dynorphin ${ }_{1-13}$, an extraordinarily potent opioid peptide. Proc Natl Acad Sci USA 1979;76:6666-6670.

-85 Kinoshita F, Nakai Y, Katakami H, Imura H: Suppressive effect of dynorphin ${ }_{1-13}$ on luteinizing hormone release in conscious castrated rats. Life Sci 1982;30:1915-1919.

-86 Goodman RL, Coolen LM, Anderson GM, Hardy SL, Valent M, Connors JM, Fitzgerald
ME, Lehman MN: Evidence that dynorphin plays a major role in mediating progesterone negative feedback on gonadotropin-releasing hormone neurons in sheep. Endocrinology 2004;145:2959-2967.

87 Zhen S, Gallo RV: The effect of blockade of $\kappa$-opioid receptors in the medial basal hypothalamus and medial preoptic area on luteinizing hormone release during midpregnancy in the rat. Endocrinology 1992;131:16501656.

88 Zhang Q, Gallo RV: Effect of prodynorphinderived opioid peptides on the ovulatory luteinizing hormone surge in the proestrous rat. Endocrine 2002;18:27-32.

89 Zhang Q, McCoy JM, Gallo RV: Further studies on possible dynorphin involvement in the ovulatory luteinizing hormone surge in the proestrous rat. Endocrine 2002;18:231-238.

90 Mansour A, Khachaturian H, Lewis ME, Akil $\mathrm{H}$, Watson SJ: Anatomy of CNS opioid receptors. Trends Neurosci 1988;11:308-314.

91 Zhen S, Gallo RV: The role of norepinephrine in mediating luteinizing hormone release in response to blockade of kappa-opioid receptors in the medial preoptic area. Brain Res 1995; 698:121-129.

92 Ito E, Mirzuno T, Kimura F: P3.36 effects of dynorphin on noradrenaline release in the rat medial preoptic area. Neuroendocrinology 1994;60:71.

93 Diez-Guerra FJ, Augood S, Emson PC, Dyer RG: Opioid peptides inhibit the release of noradrenaline from slices of rat medial preoptic area. Exp Brain Res 1987;66:378-384.

94 Herbison AE: Noradrenergic regulation of cyclic GnRH secretion. Rev Reprod 1997;2: $1-6$.

95 Medhamurthy R, Gay VL, Plant TM: The prepubertal hiatus in gonadotropin secretion in the male rhesus monkey (Macaca mulatta) does not appear to involve endogenous opioid peptide restraint of hypothalamic gonadotropin-releasing hormone release. Endocrinology 1990;126:1036-1042.

96 Barb CR, Rampacek GB, Kraeling RR, Estienne MJ, Taras E, Estienne CE, Whisnant CS: Absence of brain opioid peptide modulation of luteinizing hormone secretion in the prepubertal gilt. Biol Reprod 1988;39:603-609.

97 Ulloa-Aguirre A, Mendez JP, Gonzalez-Castillo A, Carranza-Lira S, Garza-Flores J, PeresPalacios G: Changes in the responsiveness of luteinizing hormone secretion to infusion of the opioid antagonist naloxone throughout male sexual maturation. Clin Endocrinol (Oxf) 1988;29:17-28.

98 Sauder SE, Case GD, Hopwood NJ, Kelch RP, Marshall JC: The effects of opiate antagonism on gonadotropin secretion in children and in women with hypothalamic amenorrhea. Pediatr Res 1984;18:322-328.

99 Mauras N, Rogol AD, Veldhuis JD: Appraising the instantaneous secretory rates of luteinizing hormone and testosterone in response to selective mu opiate receptor blockade in late pubertal boys. J Androl 1987;8:203-209.
00 YoungLai EV, Wilkinson M, Thompson N, Byrne A: Opioidergic control of luteinizing hormone secretion in the female rabbit: influence of age on the response to naloxone. Can J Physiol Pharmacol 1988;66:38-42.

101 Bhanot R, Wilkinson M: Opiatergic control of gonadotropin secretion during puberty in the rat: a neurochemical basis for the hypothalamic 'gonadostat'? Endocrinology 1983; 113:596-603.

102 Gill JC, Navarro VM, Kwong C, Noel SD, Martin C, Xu S, Clifton DK, Carroll RS, Steiner RA, Kaiser UB: Increased neurokinin B (Tac2) expression in the mouse arcuate nucleus is an early marker of pubertal onset with differential sensitivity to sex steroid-negative feedback than Kiss1. Endocrinology 2012;153:4883-4893.

103 Ciofi P, Lapirot OC, Tramu G: An androgen-dependent sexual dimorphism visible at puberty in the rat hypothalamus. Neuroscience 2007; 146:630-642.

104 Takumi K, Iijima N, Ozawa H: Developmental changes in the expression of kisspeptin mRNA in rat hypothalamus. J Mol Neurosci 2011;43:138-145.

105 Takase K, Uenoyama Y, Inoue N, Matsui H, Yamada S, Shimizu M, Homma T, Tomikawa J, Kanda S, Matsumoto H, Oka Y, Tsukamura H, Maeda KI: Possible role of oestrogen in pubertal increase of Kiss1/kisspeptin expression in discrete hypothalamic areas of female rats. J Neuroendocrinol 2009;21:527-537.

106 Navarro VM, Fernandez-Fernandez R, Castellano JM, Roa J, Mayen A, Barreiro ML, Gaytan F, Aguilar E, Pinilla L, Dieguez C, Tena-Sempere $\mathrm{M}$ : Advanced vaginal opening and precocious activation of the reproductive axis by KiSS- 1 peptide, the endogenous ligand of GPR54. J Physiol 2004;561:379-386.

107 Pineda R, Garcia-Galiano D, Roseweir A, Romero M, Sanchez-Garrido MA, Ruiz-Pino F, Morgan K, Pinilla L, Millar RP, TenaSempere M: Critical roles of kisspeptins in female puberty and preovulatory gonadotropin surges as revealed by a novel antagonist. Endocrinology 2010;151:722-730.

108 Rance NE: Menopause and the human hypothalamus: evidence for the role of kisspeptin/neurokinin B neurons in the regulation of estrogen negative feedback. Peptides 2009;30:111-122.

109 Topaloglu AK, Tello JA, Kotan LD, Ozbek MN, Yilmaz MB, Erdogan S, Gurbuz F, Temiz F, Millar RP, Yuksel B: Inactivating KISS1 mutation and hypogonadotropic hypogonadism. N Engl J Med 2012;366:629-635.

110 Teles MG, Bianco SD, Brito VN, Trarbach EB, Kuohung W, Xu S, Seminara SB, Mendonca BB, Kaiser UB, Latronico AC: A GPR54-activating mutation in a patient with central precocious puberty. N Engl J Med 2008;358:709-715.

111 Teles MG, Silveira LF, Tusset C, Latronico AC: New genetic factors implicated in human GnRH-dependent precocious puberty: the role of kisspeptin system. Mol Cell Endocrinol 2011;346:84-90. 